Institute of $\mathbf{F}_{\text {ood and }} \mathbf{A}_{\text {gricultural }} \mathbf{S}_{\text {ciences }}$

\title{
Species in Danger of Extinction 1
}

\section{Center for Natural Resources ${ }^{2}$}

Countless species have gone extinct from natural processes. Unfortunately we can no longer attribute the accelerating extinction of plants and animals to natural causes. Today most species of plants and animals become extinct because of habitat destruction (loss of living space to development or pollution) introduction of non-native organisms, and direct killing (overharvesting, poisoning). Since the widespread settlement of Florida in the mid-1800s, at least 19 species of animals and 12 plants are believed to have become extinct.

The Florida Fish and Wildlife Conservation Commission (FWCC) maintains the state list of 117 animals that are endangered, threatened, or species of special concern in Rules 39-27.003, 39-27.004 and 39-27.005, respectively, Florida Administrative Code (F.A.C.) The Florida Department of Agriculture and Consumer Services (FDACS) maintains the state list of 413 plants that are endangered, threatened and commercially exploited via chapter 5B-40, F.A.C. The federal lists of animals and plants are administered by the U.S. Fish and Wildlife Service and categorized into endangered and threatened, and are published in the Code of Federal Regulations
(CFR). 50 CFR, part 17, deals with animals and 50 CFR, part 23, deals with plants.

According to the USFWS listings, Florida trails only California and Hawaii, in numbers of listed endangered species. About 4 dozen other species are in as much jeopardy of extinction as those species already listed, and nearly half (44\%) of all Florida vertebrates are known or suspected to be declining in number of distribution (Figure 1).

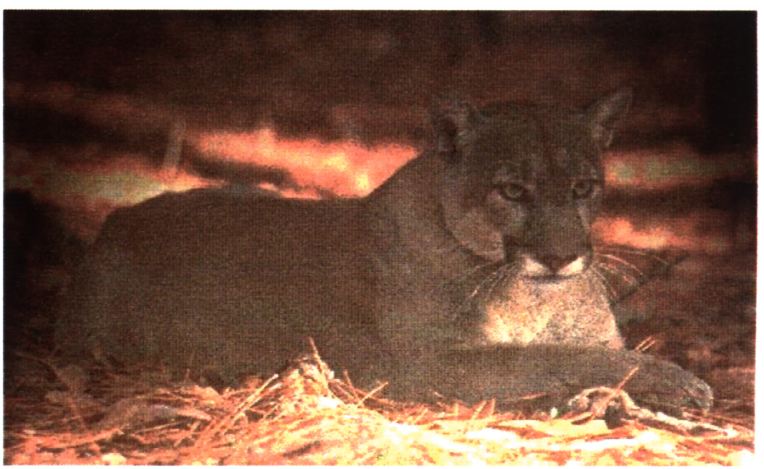

Figure 1. There are about 50 - 70 adult Florida panthers (Panthera floridanus) in the State (FWC, 2003).

Extinction occurs gradually. When an essential habitat component is diminished to a level insufficient for a species survival, that species

1. This publication was produced by the Center for Natural Resources at the University of Florida. CNR 6 is part of a Program Summary Series. First published: September 2000. Minor revision: March 2003. 1051 McCarty Hall D. Post Office Box 110230. Tel: (352) 392-7622 Fax: (352) 846-2856 Email: cnr_mail@mail.ifas.ufl.edu Web: http://cnr.ifas.ufl.edu/

2. This fact sheet was written by The Center for Natural Resources (CNR). Established in 1973, CNR, at the University of Florida, plays a major role in the conservation, preservation and restoration of our nation's natural resources by facilitating interdisciplinary collaborations between UF faculty and external stakeholders.

Nancy Peterson, Program Coordinator

The Institute of Food and Agricultural Sciences is an equal opportunity/affirmative action employer authorized to provide research, educational information and other services only to individuals and institutions that function without regard to race, color, sex, age, handicap, or national origin. For information on obtaining other extension publications, contact your county Cooperative Extension Service office. Florida Cooperative Extension Service/Institute of Food and Agricultural Sciences/University of Florida/Christine Taylor Waddill, Dean. 
becomes extinct in that area. From an individual site, extinction can then spread to township, county, state, national and global levels.

\section{University of Florida Units}

Botany Department

352-392-1175

http://web.botany.ufl.edu/

Entomology and Nematology Department

352-392-1901

http://entnemdept.ifas.ufl.edu/

Fisheries \& Aquatic Sciences Department

352-392-9617

http://fishweb.ifas.ufl.edu/

Florida Biological Diversity Project

352-846-0630

http://www.wec.ufl.edu/coop/gap/

Florida Coop. Fish \& Wildlife Research Unit 352-846-0626

http://www.wec.ufl.edu/coop/

Florida Museum of Natural History

352-846-2000

http://www.flmnh.ufl.edu/

School of Forest Resources \& Conservation 352-846-0850

http://aris.sfrc.ufl.edu/welcome.html

Governmental Responsibility Center

Levin College of Law

352-392-2237

http://www.law.ufl.edu/college/CGR/

Pathobiology Department

Veterinary Medicine College

352-392-4700

http://www.vetmed.ufl.edu/path/path.htm

Florida Sea Grant College

352-392-5870

http://www.flseagrant.org/
Wildlife Ecology \& Conservation Department 352-846-0643

http://www.wec.ufl.edu

Zoology Department

352-392-1107

http://www.zoo.ufl.edu

\section{Other Contacts}

Florida Department of Agriculture \& Consumer Services

http://doacs.state.fl.us/

Florida Fish \& Wildlife Conservation

Commission

http://southeast.fws.gov/maps/fl.html

Florida Biological Diversity Project

941-947-3567

http://www.wec.ufl.edu/coop/GAP/Default.htm

Florida Internet Center for Understanding

http://www.ficus.usf.edu/

Florida Natural Areas Inventory

http://www.fnai.org/

National Audubon Society

http://www.audubon.org/campaign/esa

The Nature Conservancy - FL Chapter

http://nature.org/wherewework/northamerica/ states/florida/

U.S. Fish \& Wildlife Service

http://www.fws.gov/ 